\title{
Communication
}

[Comunicação]

\section{Tick-borne pathogens infecting dogs from a highland swamp area}

\author{
[Infecção em cães por patógenos transmitidos por carrapatos em uma área \\ de brejo de altitude]
}

\author{
G.M.M.R. Barros ${ }^{1}$, J.C.P. Oliveira2, T.R.M. Silva², L.O. Macedo ${ }^{2}$, \\ M.A.B. Santos ${ }^{3}$, C.A.N. Ramos ${ }^{4}$, G.A. Carvalho ${ }^{5}$, R.A.N. Ramos ${ }^{5 *}$
}

\author{
${ }^{1}$ Aluno de graduação - Universidade Federal do Agreste de Pernambuco - Garanhuns, PE \\ ${ }^{2}$ Aluno de pós-graduação - Universidade Federal do Agreste de Pernambuco - Garanhuns, PE \\ ${ }^{3}$ Aluno de pós-graduação - Department of Veterinary Medicine - University of Bari - Valenzano, Italy \\ ${ }^{4}$ Faculdade de Medicina Veterinária e Zootecnia - Universidade Federal de Mato \\ Grosso do Sul - Campo Grande, MS \\ ${ }^{5}$ Universidade Federal do Agreste de Pernambuco - Garanhuns, PE
}

Canine vector-borne diseases (CVBDs) are important illnesses that affect dogs worldwide. The etiological agents of CVBDs are pathogens transmitted by blood-sucking arthropods (e.g., ticks, fleas, mosquitoes and sandflies) widely present in tropical and subtropical regions (Otranto et al., 2009). Among these vectors, the so-called "brown dog tick" named Rhipicephalus sanguineus sensu lato (s.l.) is the main tick species infesting dogs worldwide (Gray et al., 2013). This arthropod displays major negative impacts on the health of dogs due to its vector role of several pathogens (e.g., Babesia spp., Cercopithifilaria spp., Ehrlichia spp., Hepatozoon spp., Rickettsia spp.) that are of considerable medical and veterinary concern (Ramos et al., 2010; Santos et al., 2017). Animals affected by tick-borne pathogens (TBPs) may present clinical or subclinical infection, and in some cases, they may act as reservoirs (Shaw et al., 2001).

In Brazil, Babesia spp., Erhlichia spp. and Anaplasma spp. are the most common TBPs infecting dogs (Ramos et al., 2010). Babesiosis, caused by the protozoa Babesia vogeli, is usually associated with apathy, weakness, anorexia, pale mucous and poor general condition of the patients (Solano-Gallego et al., 2016). Dogs presenting Anaplasmosis and/or Ehrlichiosis, caused by the intracellular bacteria Anaplasma platys and
Ehrlichia canis, respectively, commonly present clinical signs such as thrombocytopenia, anorexia, fever, and hemostatic and digestive disorders (Yabsley et al., 2007). Co-infections by these pathogens are commonly observed as they are primarily transmitted by the same vector (Yabsley et al., 2007). This is particularly important due to influences on the clinical presentation and on the treatment protocol employed.

In the last decades, a few factors (e.g., urbanization, climate change and deforestation) have contributed to the emergence and reemergence of many TBPs (Kamani et al., 2013), in particular, the climate change (Jaenson et al., 2012). For instance, in Northeastern Brazil, there is an area featured by a high-altitude swamp that exhibits an atypical climatic condition (i.e., low temperatures in part of the year, high relative humidity and rainfall), which is not observed in other parts of the region. In this area the ecoepidemiology of $R$. sanguineus s.l. and associated TBPs has been poorly studied; therefore, the aim of this study was to detect TBPs of dogs living in an area characterized by a high-altitude swamp.

The study was conducted in the urban area of the municipality of Garanhuns (8 53 '25' South and $36^{\circ} 29^{\prime} 34^{\prime \prime}$ 'West), state of Pernambuco, Northeastern Brazil. This area has a population of

Recebido em 6 de agosto de 2020

Aceito em 19 de fevereiro de 2021

*Autor para correspondência (corresponding author)

E-mail:rafael.ramos@ufape.edu.br 
139,788 inhabitants distributed over 12 neighborhoods. It presents a tropical climate, with an annual mean temperature of $20^{\circ} \mathrm{C}$ (ranging from $16^{\circ} \mathrm{C}$ to $30^{\circ} \mathrm{C}$ ), annual mean rainfall of $873 \mathrm{~mm}$ (ranging from 751 to 1000 $\mathrm{mm})$, and average relative humidity of $76 \%$ (ranging from $38 \%$ to $100 \%$ ). In addition, it is located at $900 \mathrm{~m}$ above sea level and the wet season occurs from April to July. Most of the municipality, including its urban area is inserted in the so-called highland swamp, which is part of the Northeastern Atlantic forest that has progressively been degraded by the advancement of urbanization.

Sample size was estimated based on the domiciled canine population $(\sim 13,700)$ in the municipality of Garanhuns (95\% C.I.), with an estimated TBPs prevalence of $50 \%$. The estimated dog population was determined based on WHO (Guidelines for dog population management, 1990). Blood samples $(n=203)$ of owned dogs were collected through puncture of cephalic vein, stored in plastic tubes containing ethylenediamine tetra acetic acid (EDTA/K3; Vacuette ${ }^{\circledR}$, Greiner BioOne, SP, Brazil) and preserved at $-20^{\circ} \mathrm{C}$ until molecular processing. Samples were collected from all 12 neighborhoods (mean of $17 \pm 2 \mathrm{dogs}$ per neighborhood) and data on the clinical evaluation of each animal was recorded in individual charts. Genomic DNA extraction was performed using a protocol previously described (Araújo et al., 2009). Samples were PCR screened for DNA of TBPs using primers based on the $16 \mathrm{~S}$ and 18S rRNA gene (Table 1). Nested PCR was used for detection of E. canis and A. platys, and conventional PCR for B. canis and Hepatozoon spp. All reactions included positive and negative controls. The PCR products were subjected to electrophoresis in a $1.5 \%$ agarose gel, stained with BlueGreen ${ }^{\circledR}$ (LGC-Biotechnology) and GelRed $^{\mathrm{TM}}$ (Biotium, Hayward, CA), and viewed under an UV transilluminator.

Table 1. Primers used in PCR for detection of DNA of Ehrlichia canis, Anaplasma platys, Babesia vogeli and Hepatozoon sp. in dogs

\begin{tabular}{|c|c|c|c|c|}
\hline Pathogens & $\begin{array}{l}\text { Target } \\
\text { gene }\end{array}$ & Primer / Sequence $\left(5^{\prime}-3^{\prime}\right)$ & $\begin{array}{l}\text { Size } \\
\text { (bp) }\end{array}$ & Reference \\
\hline $\begin{array}{l}\text { Ehrlichia } \\
\text { canis }\end{array}$ & $\begin{array}{c}16 \mathrm{~S} \\
\text { rRNA }\end{array}$ & $\begin{array}{c}\text { ECC / AGAACGAACGCTGGCGGCAAGCC } \\
\text { ECB / CGTATTACCGCGGCTGCTGGC }\end{array}$ & 478 & $\begin{array}{l}\text { Wen et al. } \\
\text { (1997) }\end{array}$ \\
\hline $\begin{array}{l}\text { Ehrlichia } \\
\text { canis }\end{array}$ & $\begin{array}{c}16 \mathrm{~S} \\
\text { rRNA }\end{array}$ & $\begin{array}{c}\text { HE / TATAGGTACCGTCATTATCTTCCCTAT } \\
\text { ECA / } \\
\text { CAATTATTTATAGCCTCTGGCTATAGGAA }\end{array}$ & 389 & $\begin{array}{l}\text { Wen et al. } \\
\quad(1997)\end{array}$ \\
\hline $\begin{array}{l}\text { Anaplasma } \\
\text { platys }\end{array}$ & $\begin{array}{l}16 \mathrm{~S} \\
\text { rRNA }\end{array}$ & $\begin{array}{c}\text { 8F / AGTTTGATCATGGCTCAG } \\
\text { 1448R / CCATGGCGTGACGGGCAGTGTG }\end{array}$ & - & $\begin{array}{l}\text { Martin et al. } \\
\quad(2005)\end{array}$ \\
\hline $\begin{array}{l}\text { Anaplasma } \\
\text { platys }\end{array}$ & $\begin{array}{l}16 \mathrm{~S} \\
\text { rRNA }\end{array}$ & $\begin{array}{l}\text { PLATYS-F / GATTTTTGTCGTAGCTTGCTATG } \\
\text { EHR16S-R / TAGCACTCATCGTTTACAGC }\end{array}$ & 678 & $\begin{array}{l}\text { Martin et al. } \\
\quad(2005)\end{array}$ \\
\hline $\begin{array}{l}\text { Babesia } \\
\text { vogeli }\end{array}$ & $\begin{array}{l}18 \mathrm{~S} \\
\text { rRNA }\end{array}$ & $\begin{array}{l}\text { BAB1 / GTGAACCTTATCACTTAAAG } \\
\text { BAB4 / CAACTCCTCCACGCAATCG }\end{array}$ & 590 & $\begin{array}{l}\text { Duarte et al. } \\
\quad(2008)\end{array}$ \\
\hline $\begin{array}{l}\text { Hepatozoon } \\
\text { sp. }\end{array}$ & $\begin{array}{l}18 \mathrm{~S} \\
\text { rRNA }\end{array}$ & $\begin{array}{l}\text { HepF / ATACATGAGCAAAATCTCAAC } \\
\text { HepR / CTTATTATTCCATGCTGCAG }\end{array}$ & 666 & $\begin{array}{c}\text { Inokuma et } \\
\text { al. (2002) }\end{array}$ \\
\hline
\end{tabular}

The amplicons were purified using ExoSAP-IT PCR Product Cleanup Reagent (Applied Biosystems by Thermo Fisher Scientific - BR) and sequenced by Sanger's method (Sanger et al., 1977) in an automated sequencer ABI3130 (Applied Biosystems). Sequences were aligned using the BioEdit v.7.2.5 program (Hall, 1999) and compared with those available in the GenBank $^{\text {TM }}$ database via BLAST analysis (Altschul et al., 1990). Data analysis was performed through descriptive statistics to obtain absolute and relative frequencies. In addition, the positivity according to the sex was evaluated by means of the Fisher Exact Test. The significance level was set up at 5\%. All analyses were carried out using the statistical software BioEstat version 5.3 (Ayres et al., 2007). The Ethics Committee for Animal Experimentation (ECAE) of the Universidade Federal Rural de Pernambuco approved the study (protocol number: 99/2016). Out of all animals enrolled $(\mathrm{n}=203) 46.80 \%$ $(95 / 203)$ were female and $53.20 \%(108 / 203)$ were male, with age ranging from two months to 18 years. None of the animals presented clinical signs associated to TBPs infection; however, ticks 
( $R$. sanguineus s.l.) were detected in the majority of positive animals $(61.1 \% ; 11 / 18)$.

Of all analyzed samples $8.87 \%(18 / 203)$ scored positive, with a frequency of $5.42 \%(11 / 203)$ for A. platys and $3.45 \%$ (7/203) for E. canis (Table 2). No statistical difference was observed among positive animals and sex $(\mathrm{p}=0.45)$. All samples were negative for Babesia spp. and Hepatozoon spp., and co-infections were not detected. DNA sequencing of the amplified products revealed a homology of $100 \%$ with E. canis and A. platys sequences available on the Genbank database. The DNA sequences obtained in the present study were deposited in the Genbank under the access numbers shown in the Table 2.

Table 2. Frequency of Anaplasma platys and Ehrlichia canis according to the gender of dogs and sequence access numbers deposited in Genbank

\begin{tabular}{lccc}
\hline \multicolumn{1}{c}{ Pathogen } & \multicolumn{2}{c}{ Gender } & Access numbers \\
\hline & Male & Female & \\
$\begin{array}{l}\text { Anaplasma } \\
\text { platys }\end{array}$ & & & MT229115, MT229116, MT229117, \\
& $4.62 \%(5 / 108)$ & $6.31 \%(6 / 95)$ & MT229118, MT229119, MT229120, \\
& & & MT229121, MT229122, MT229123, \\
& & MT229124 and MT229125 \\
Ehrlichia canis & $4.62 \%(5 / 108)$ & $2.10 \%(2 / 95)$ & MT229107, MT229108, MT229109, \\
& & & MT229111, MT229112 and \\
\end{tabular}

This study provides molecular evidence of infection by $A$. platys and E. canis in dogs living in an area characterized by a high-altitude swamp in Northeastern Brazil. Though common in tropical regions, these pathogens have never been reported in the studied area. The overall positivity herein detected (i.e., 8.87\%; 18/203) follows a trend observed in other regions; however, it was lower than that observed in a previous study conducted in a different area of Northeastern Brazil (i.e., 38.04\%; 79/205) (Ramos et al., 2010). Several factors such as canine population, vector dynamics and diagnostic methods may contribute to such differences (Solano-Gallego et al., 2016).

The low frequency herein reported for TBPs (i.e., $5.42 \%$ for A. platys and $3.45 \%$ for E. canis) may be related to the animal population studied, as none of the enrolled dogs presented clinical signs associated with TBPs infections. Nevertheless, $A$. platys and $E$. canis are responsible for high morbidity in dogs. The role of $R$. sanguineus s.l. as a vector for $A$. platys has been speculated, based on the cases of co-infections with $E$. canis (Ramos et al., 2009) and on the detection of this bacteria in ticks (Ramos et al., 2014). Recently, the vector competence for this pathogen has been proved in experimental study (Snellgrove et al., 2020).

The negative results for Babesia spp. and Hepatozoon spp. do not indicate the absence of both pathogens in the study area. For instance, $H$. canis was reported in $R$. sanguineus s.l. ticks collected from dogs in rural environments of the same municipality (Santos et al., 2017). Most likely, factors related to sampling period, as well as to the targeted dog population may have influenced this finding. Additionally, $R$. sanguineus s.l. population dynamics in the study area is unknown, and this information is pivotal to better understand the period of occurrence of TBPs in susceptible hosts. Another factor that may have influenced the results herein obtained, is the atypical weather conditions (i.e., low temperatures from April to August and high annual average rainfall) of the study area, which is also featured by a high-altitude swamp that does not allow abundant parasitism by ticks on dogs during the whole year, possibly reflecting on the reduced pathogen transmission.

Most of the positive animals were found to be infested by $R$. sanguineus s.l. ticks, the vector role of which has been extensively studied worldwide. Over the last years, discussions about the existence of different lineages (i.e., temperate and tropical lineages) of $R$. sanguineus s.l. have increased throughout the world (Moraes-Filho et al., 2011; Dantas-Torres et al., 2018). The vectorial competence of these two lineages may differ. For example, a study on $R$. sanguineus s.l. evaluated its vectorial role for $E$. canis in four tick populations from different geographic regions of South America, demonstrating that only the tropical lineage group was a competent vector for 
the pathogen (Moraes-Filho et al., 2015). Interestingly, the region of the group with vectorial competence is highly endemic for ehrlichiosis, whereas in the other three regions, where the ticks are of the temperate lineage, the pathogen has not been properly reported (MoraesFilho et al., 2015).

This study provides the first scientific evidence of the presence of $A$. platys and E. canis in dogs in an area featured by a high-altitude swamp, and although the molecular analyses of ticks has not been performed, the data herein presented reinforces the role of $R$. sanguineus s.l. as vector of A. platys, since positive animals were infested by this tick species. Finally, preventive measures against ectoparasites are advocated for dogs living in this area to reduce the risk of TBPs transmission.

Keywords: dogs, Anaplasma platys, Ehrlichia canis

\section{RESUMO}

Objetivou-se neste estudo relatar a frequência e a identidade de patógenos transmitidos por carrapatos em cães residentes de uma área caracterizada por brejo de alta altitude. Amostras sanguíneas (n=203) foram coletadas e molecularmente analisadas via PCR (Babesia spp., Hepatozoon spp., Anaplasma spp. e Ehrlichia spp.) e sequenciamento de DNA. De todas as amostras analisadas, 8,87\% (18/203) foram positivas a algum patógeno transmitido por carrapato. Especificamente, 5,42\% (11/203) e 3,45\% (7/203) foram positivos a Anaplasma platys $e$ Ehrlichia canis, respectivamente. Este estudo fornece, pela primeira vez, evidência científica de infecção de cães por esses patógenos nessa área de alta altitude e reforça o provável papel de R. sanguineus s.l. como vetor de A. platys, principalmente considerando.se que muitos animais positivos eram infestados por essa espécie de carrapato.

Palavras-chave: cães, Anaplasma platys, Ehrlichia canis

\section{ACKNOWLEDGEMENTS}

This article is based on a project executed by the first author, developed at the Federal University of the Agreste of Pernambuco, with support from a fellowship from Fundação de Amparo a Ciência e Tecnologia do Estado de Pernambuco (FACEPE).

\section{REFERENCES}

ALTSCHUL, S.F.; GISH, W.; MILLER, W.; MYERS, E.W.; LIPMAN, D.J. Basic local alignment search tool. J. Mol. Biol. Res., v.215, p.403-410, 1990.

ARAÚJO, F.R.; RAMOS, C.A.N.; LUÍZ, H.L. et al. Avaliação de um protocolo de extração de DNA genômico a partir de sangue total. Campo Grande: Embrapa, 2009. 5p. (Comunicado Técnico, n.120)

AYRES, M.; AYRES, J.; AYRES D.L.; SANTOS, A.S. BioEstat 5.0: aplicações estatísticas nas áreas de ciências bio-médicas. Amazonas: Sociedade Civil Mamirauá, 2007. 380p.
DANTAS-TORRES, F.; LATROFA, M.S.; RAMOS, R.A.N. et al. Biological compatibility between two temperate lineages of brown dog ticks, Rhipicephalus sanguineus (sensulato). Parasit. Vectors, v.11, p.398, 2018.

DUARTE, S.C.; LINHARES, G.F.C.; ROMANOWSKY, T.N.; SILVEIRA NETO, O.J.; BORGES, L.M.F. Assessment of primers designed for the subspecies-specific discrimination among Babesia canis canis, Babesia canis vogeli and Babesia canis rossi by PCR assay. Vet. Parasitol., v.152, p.16-20, 2008.

GRAY, J.; DANTAS-TORRES, F.; ESTRADAPEÑA, A.; LEVIN, M. Systematics and ecology of the brown dog tick, Rhipicephalus sanguineus. Ticks Tick Borne Dis., v.4, p.171-80, 2013.

GUIDELINES for dog population management. Geneva: WHO, 1990. Available in: https://apps.who.int/iris/handle/10665/61417. Acessed in: 30 Mar. 2020

HALL, T.A. BioEdit: a user-friendly biological sequence alignment editor and analysis program for windows 95/98/NT. Nucl. Acids. Symp. Ser., v.41, p.95-98, 1999. 
INOKUMA, H.; FUJII, K.; MATSUMOTO, K. et al. Demonstration of Anaplasma (Ehrlichia) platys inclusions in peripheral blood platelets of a dog in Japan. Vet. Parasitol., v.110, p.145-152, 2002

JAENSON, T.G.; JAENSON, D.G.; EISEN, L.; PETERSSON, E.; LINDGREN, E. Changes in the geographical distribution and abundance of the tick Ixodes ricinus during the past 30 years in Sweden. Parasit. Vectors, v.5, p.8, 2012.

KAMANI, J.; BANETH, G.; MUMCUOGLU, K.Y. et al. Molecular detection and characterization of tick-borne pathogens in dogs and ticks from Nigeria. PLoS Negl. Trop. Dis., v.7, p.e2108, 2013.

MARTIN, A.R.; BROWN, G.K.; DUNSTAN, R.H.; ROBERTS, T.K. Anaplasma platys: an improved PCR for its detection in dogs. Exp. Parasitol., v.109, p.176-180, 2005.

MORAES-FILHO, J.; KRAWCZAK, F.S.; COSTA, F.B.; SOARES, J.F.; LABRUNA, M.B. Comparative evaluation of the vector competence of four South American populations of the Rhipicephalus sanguineus group for the bacterium Ehrlichia canis, the agent of canine monocytic Ehrlichiosis. PLoS One., v.10, p.e0139386, 2015.

MORAES-FILHO, J.; MARCILI, A.; NIERIBASTOS, F.A.; RICHTZENHAIN, L.J.; LABRUNA, M.B. Genetic analysis of ticks belonging to the Rhipicephalus sanguineus group in Latin America. Acta Trop., v.117, p.51-55, 2011.

OTRANTO, D.; DANTAS-TORRES, F.; BREITSCHWERDT, E.B. Managing canine vector-borne diseases of zoonotic concern: part two. Trends Parasitol., v.25, p.228-235, 2009.

RAMOS, C.A.; RAMOS, R.A.; ARAÚJO, F.R. et al. Comparison of nested-PCR with blood smear examination in detection of Ehrlichia canis and Anaplasma platys in dogs. Rev. Bras. Parasitol. Vet., v.18, p.58-62, 2009.
RAMOS, R.; RAMOS, C.; ARAÚJO, F. et al. Molecular survey and genetic characterization of tick-borne pathogens in dogs in metropolitan Recife (north-eastern Brazil). Parasitol. Res., v.107, p.1115-1120, 2010.

RAMOS, R.A.; LATROFA, M.S.; GIANNELLI, A. et al. Detection of Anaplasma Platys in dogs and Rhipicephalus sanguineus group ticks by a quantitative real-time PCR. Vet. Parasitol., v.205, p.285-288, 2014.

SANGER, F.; NICKLEN, S.; COULSON, A.R. DNA sequencing with chain-terminating inhibitors. Proc. Natl. Acad. Sci., v.74, v.54635467, 1977.

SANTOS, M.A.B.; SOUZA, I.B.; MACEDO, L.O. et al. Cercopithifilaria bainae in Rhipicephalus sanguineus sensu lato ticks from dogs in Brazil. Ticks Tick Borne Dis., v.8, p.623625, 2017.

SHAW, S.E.; DAY, M.J.; BIRTLES, R.J.; BREITSCHWERDT, E.B. Tick-borne infectious diseases of dogs. Trends Parasitol., v.17, p.74-80, 2001.

SNELLGROVE, A.N.; KRAPIUNAYA, I.; FORD, S.L.; STANLEY, H.M.; WICKSON, A.G.; HARTZER; K.L.; LEVIN, M.L. Vector competence of Rhipicephalus sanguineus sensu stricto for Anaplasma platys. Ticks Tick Borne Dis., v.11, p.101517, 2020.

SOLANO-GALLEGO, L.; SAINZ, Á.; ROURA, X.; ESTRADA-PEÑA, A.; MIRÓ, G. A review of canine babesiosis: the European perspective. Parasit. Vectors, v.9, 2016.

WEN, B.; RIKIHISA, Y.; MOTT, J.M. et al. Comparison of nested PCR with imunofluorescent antibody assay for detection of Ehrlichia canis infection in dogs treated with doxycycline. J. Clin. Microbiol., v.35, p.18521855, 1997.

YABSLEY, M.J.; MCKIBBEN, J.; MACPHERSON, C.N. et al. Prevalence of Ehrlichia canis, Anaplasma Platys, Babesia canis vogeli, Hepatozoon canis, Bartonella vinsonii berkhoffi, and Rickettsia spp. in dogs from Grenada. Vet. Parasitol., v.151, p.279-285, 2007. 